Received: 05 September 2019

Accepted: 06 December 2019

Online: 10 December 2019

Authors:

J. K. Momin $₫$

Department of Food Quality Assurance, College of Food Processing Technology and Bio-Energy, Anand Agricultural University, Anand 388 110, Gujarat, India

J. B. Prajapati

SMC College of Dairy Science, Anand

Agricultural University, Anand 388 110, Gujarat

$\bigotimes$ mominjk@gmail.com,jkmomin@aau.in

Emer Life Sci Res (2019) 5(2): 35-42

E-ISSN: 2395-6658

P-ISSN: 2395-664X

DOI: https://doi.org/10.31783/elsr.2019.523542

\section{Research Article \\ Effect of selected medicinal herbs on viability and acid production of lactic dairy starters}

\author{
J. K. Momin, J. B. Prajapati
}

\begin{abstract}
Four medicinal herbs viz., Zingiber officinale (Ginger), Asparagus racemosus (Satavari), Chlorophytum borivillianum (Safed Musli) and Withania somnifera (Ashwagandha) were evaluated for their antimicrobial/stimulatory effects on four selected lactic acid bacteria viz., Lactobacillus helveticus MTCC 5463, Lactobacillus rhamnosus MTCC 5462, Streptococcus thermophilus MTCC 5460 and Streptococcus thermophilus MTCC 5461 by cup well assay technique as well as by observing changes in $\mathrm{pH}$, acidity and viable lactic acid bacterial counts in skimmed milk in the presence of medicinal herbs (@1\%). Safed Musli and ginger did not show any inhibition to any of the tested lactic cultures. Satavari had shown very little inhibition, while Ashwagandha powder significantly inhibited the growth of all the lactic cultures with maximum effect on Lb. helveticus MTCC 5463. The $\mathrm{pH}$ ranged from 4.67 to 5.35 , and the percent lactic acid ranged from 0.44 to 0.67 . The log viable count ranged from 7.15 to 9.40 in the herbs added fermented milk while control ranged from 8.07 to 9.4. The increase in the log viable count was least in the fermented milk with ashwagandha. The ginger and Safed Musli added milk had either no or least inhibitory effect on viable lactic bacterial count compared to the control during fermentation. However, with culture Streptococcus thermophilus MTCC 5461, the log count was higher in ginger (9.42) and Safed Musli (9.40) added fermented milk as compared to the control (9.38) indicating a supportive role.
\end{abstract}

Keywords fermented milk, lactic acid bacteria, medicinal herbs, probiotics

\section{Introduction}

The health and nutrition consciousness among consumers is stimulating the demand for nutritive, healthy and functional foods [1]. Lactic acid bacteria (LAB) are generally regarded as safe [2-3] and hence, used in the manufacturing of different types of fermented milk and dairy products including yogurt, dahi, cultured buttermilk, lassi, sour cream, kefir, koumiss, and cheese [3-4]. More than $65 \%$ of the functional foods have been known to be prepared from milk as the raw material because of its proven nutritional benefits to humanity since medieval times. The health benefits of fermented milk and milk products are due to the biologically active components present in the milk and the health modulation activity by the probiotic microorganism present [4]. Herbs and spices are used to impart an aroma and taste to food. Several herbs have therapeutic properties such as anti-oxidative, antiinflammatory, anti-diabetic, anti-hypertensive, anti-microbial activities and immune-modulatory properties [5-6]. Spices and herbs that are added during food preparation, control the microbial contaminants and prevent the spoilage 
of foods [7-8]. The effect of herbs on the activity of mesophilic cheese starter cultures was studied by Coşkun [9] and found that herbs stimulate the acid production by Lactococcus lactis subsp. lactis and $L$. lactis subsp. Cremoris. Zaika and Kissinger [10] investigated the effects of some spices on the growth and activities of Lactobacillus plantarum and Pediococcus cerevisiae bacteria that are used in meat technology. In addition, some herbs stimulated acid production by L. plantarum and Pediococcus acidilactici. Chan et al. [6] reported that the phenolic rich extracts had inhibitory activity against food-borne pathogenic bacteria, but not against LAB. However, there is no information available regarding the effect of local herbs powder on the activity of indigenous lactic dairy starters.

Potential probiotic strains L. helveticus MTCC 5463 and Lactobacillus rhamnosus MTCC 5462 [11] have a strong antimicrobial effect against various Gram-positive and Gram-negative bacteria [7]. These isolates have been previously studied for their hypocholesterolemic effect in humans [12]; immunostimulating activity in chicks [13] and adhesion capabilities in the CaCo-2 cell lines [14]. $S$. thermophilus MTCC 5460 and S. thermophilus MTCC 5461 are curd isolates, extensively studied for manufacturing of curd, lassi, and yoghurt, either alone or in combination with Lactobacilli [7, 15-16].

Zingiber officinale (Ginger), Asparagus racemosus (Satavari), Chlorophytum borivillianum (Safed musli) and Withania somnifera (Ashwagandha) are very well known medicinal herbs since ancient times and are recognized in the ayurvedic medicine system for conferring various health benefits. The effect of these herbs against technologically potential lactic acid bacteria is not reported in the literature and hence, the present investigation was undertaken to check the effect of these herbs against four indigenous lactic dairy starters used in milk fermentation.

\section{Methodology}

\section{Lactic dairy cultures}

Two strains of lactobacilli viz., Lactobacillus helveticus MTCC 5463, Lactobacillus rhamnosus MTCC 5462 and two strains of streptococci viz., Streptococcus thermophilus MTCC 5460 and Streptococcus thermophilus MTCC 5461 were obtained from the culture collection of Dairy Microbiology Department, SMC College of Dairy Science, Anand Agricultural University, Anand. They were maintained and propagated in sterilized reconstituted skim milk (10\% Total Solids) followed by the incubation at $37^{\circ} \mathrm{C}$ for 8 $\mathrm{h}$ and stored at $5+2^{\circ} \mathrm{C}$ during the entire course of the study. Prior to use, three successive transfers of cultures were given in sterilized skim milk to activate cultures. All bacteriological media were purchased from Sigma (Germany) or Hi-Media (Mumbai, India) while analytical grade chemicals were obtained from Merch (Germany) or SDFCL (Mumbai, India).

\section{Medicinal herbs extract powder}

Four Indian medicinal herbs namely Zingiber officinale (Ginger), Asparagus racemosus (Satavari), Chlorophytum borivillianum (Safed musli), Withania somnifera (Ashwagandha) powder were considered for the study. Complimentary extract powder of medicinal herbs was supplied by M/S Green Chem. Ltd. Bangalore. UV radiation treatment for 30 minutes was used for sterilization of medicinal herbs powder. After sterilization, the herbs were tested for inhibitory/stimulatory effect by cup well assay technique as well as by fermentation study in skim milk.

\section{Stimulatory/inhibitory activity evaluation}

Stimulatory or inhibitory activity of the herbs against selected dairy cultures was determined by cup well assay technique as per the British standard Method (BS:4020,1974) with slight modification. For Lactobacillus helveticus MTCC 5463 and Lactobacillus rhamnosus MTCC 5462, de Mann-Rogosa-Sharpe (MRS) agar medium was used, while for Streptococcus thermophilus MTCC 5460 and Streptococcus thermophiles MTCC 5461, M17 agar base was used. Double layered MRS/M17 agar plates were prepared with added lactic acid bacteria (@2\% v/v). In each plate, five wells were made at an equal distance using a sterilized hollow stainless steel gel cutter $(7 \mathrm{~mm}$ diameter). The aqueous solution of four medicinal plants extracts powder was transferred in wells individually, whereas, the fifth (center) well was filled with the 
same quantity of sterilized distilled water as a control. Plates were kept undisturbed for 1 hour to facilitate the diffusion of medicinal plants solution in agar plates. These plates were incubated at $37^{\circ} \mathrm{C}$ and after every 6 hours, observation for inhibition/stimulation zones was taken to check the effects.

\section{Milk fermentation}

Skim milk (12\% dry matter) was used as a fermentation medium for study. UV sterilized medicinal herb powder was incorporated @ $1 \%$ in skim milk during the process of heating ( $90^{\circ} \mathrm{C}$ for 5 minutes). This milk was cooled to $40^{\circ} \mathrm{C}$ and inoculated with $2 \%$ individual cultures and fermented at $37^{\circ} \mathrm{C}$ for $8 \mathrm{~h}$. The product was analyzed for $\mathrm{pH}$, percent lactic acid and viable count of lactic acid bacteria just after the inoculation of milk and after $8 \mathrm{~h}$ of fermentation. Milk without herb powder was used as a control during the entire study.

\section{Determination of Titratable Acidity of milk}

The titratable acidity of fermented milk was measured as percent lactic acid from the product during the entire study as per the method of IS: 1469, part I [17], using $10 \mathrm{~mL}$ of sample.

\section{Determination of milk $\mathrm{pH}$}

The $\mathrm{pH}$ of skim milk was determined using electronic $\mathrm{pH}$ meter, Model CYBERSCAN 2100 manufactured by EUTECH Instruments, Singapore.

\section{Enumeration of lactic acid bacteria of milk}

Enumeration of lactic acid bacteria was done using conventional pour plate techniques. Lactobacilli count enumeration was carried out as per the method described in IDF standards [18] while Streptococci count was done as per the protocol described in Bureau of Indian Standards [19]. de Mann-Rogosa-Sharpe (MRS) agar medium was used for Lactobacillus helveticus MTCC 5463 and Lactobacillus acidophilus, while M17 agar base was used for Streptococcus thermophilus MTCC 5460 and Streptococcus thermophiles MTCC 5461, throughout the study. Double layered agar plates were prepared in duplicates. The plates were incubated at $37+2^{\circ} \mathrm{C}$ for $48 \mathrm{~h}$. After incubation, plates were counted for the colonies. The count was expressed as $\mathrm{cfu} / \mathrm{ml}$.

\section{Results and Discussion}

\section{Stimulatory/inhibitory effect of selected medicinal herbs}

The primary stimulatory or inhibitory effect of medicinal herbs on lactic dairy bacteria assessed by cup well assay technique is shown in Table 1. Ginger and Safed Musli did not show any inhibition to any of the lactic dairy cultures tested and the effect was comparable to the control. Satavari had shown very little inhibition against all the cultures. Ashwagandha powder had significantly inhibited the growth of all the cultures and the maximum inhibitory effect was observed against Lactobacillus helveticus MTCC 5463. Lee and Ahn [20] observed the weak growth-inhibiting activity of Cinnamomum cassia (Blume) barkderived materials toward intestinal L. acidophilus as compared to other bacteria using an impregnated paper disk method.

Table 1. Effects of medicinal herbs on lactic dairy bacteria

\begin{tabular}{|l|c|c|c|c|}
\hline \multirow{2}{*}{ Herbs } & \multicolumn{4}{c|}{ Culture } \\
\cline { 2 - 5 } & MD2 & MD8 & V3 & I4 \\
\hline Control (Sterilized water) & - & - & - & - \\
\hline A (Ashwagantha powder solution) & ++ & ++ & +++ & ++ \\
\hline G (Ginger Powder solution ) & - & - & - & - \\
\hline S (Satavari powder solution) & + & + & + & + \\
\hline SM (Safed Musli powder solution) & - & - & - & - \\
\hline$-\quad$ : No inhibition (6 mm bore diameter only) \\
$+\quad$ : Slight inhibition (up to 7 mm) \\
++ : Moderate inhibition (8 to $9 \mathrm{~mm})$ \\
+++ : Higher inhibition (10 to $11 \mathrm{~mm}$ )
\end{tabular}


As all the four herbs are a rich source of carbohydrates and potential prebiotics components, they were further tested for their suitability for their incorporation in milk and their effects on $\mathrm{pH}$, titratable acidity (\% lactic acid) and lactic acid bacteria count during the process of fermentation (Table 2 ).

Table 2. Effects of medicinal herbs powder on pH, Titratable acidity (\% lactic acid) and viability of lactic acid bacteria in fermented milk

\begin{tabular}{|c|c|c|c|c|c|c|c|}
\hline \multirow{2}{*}{ Samples No. } & \multicolumn{3}{|c|}{ Just after inoculation $(0 \mathrm{~h})$} & \multicolumn{3}{|c|}{ After fermentation $(8 \mathrm{~h})$} & \multirow[b]{2}{*}{$\begin{array}{c}\text { log viable } \\
\text { count } \\
\text { change } \\
\text { after } 8 \mathrm{~h} \\
\text { fermentati } \\
\text { on }\end{array}$} \\
\hline & $\mathrm{pH}$ & $\begin{array}{l}\text { Acidity } \\
\text { (\%Lactic } \\
\text { acid) }\end{array}$ & $\begin{array}{c}\text { Log } \\
\text { viable } \\
\text { count } \\
(\mathrm{cfu} / \mathrm{ml})\end{array}$ & $\mathrm{pH}$ & $\begin{array}{l}\text { Acidity } \\
\text { (\%Lactic } \\
\text { acid) }\end{array}$ & $\begin{array}{c}\text { Log } \\
\text { viable } \\
\text { count } \\
(\mathrm{cfu} / \mathrm{ml})\end{array}$ & \\
\hline $\mathrm{V} 3+\mathrm{C}$ & 6.53 & 0.23 & 6.79 & 4.71 & 0.61 & 8.42 & 1.63 \\
\hline $\mathrm{V} 3+\mathrm{G}$ & 6.48 & 0.23 & 6.79 & 4.67 & 0.59 & 8.12 & 1.33 \\
\hline $\mathrm{V} 3+\mathrm{A}$ & 6.17 & 0.32 & 6.79 & 5.17 & 0.50 & 7.66 & 0.87 \\
\hline $\mathrm{V} 3+\mathrm{S}$ & 6.26 & 0.34 & 6.79 & 4.89 & 0.63 & 7.86 & 1.07 \\
\hline $\mathrm{V} 3+\mathrm{SM}$ & 6.22 & 0.32 & 6.79 & 4.91 & 0.57 & 8.01 & 1.22 \\
\hline $\mathrm{I} 4+\mathrm{C}$ & 6.49 & 0.22 & 6.65 & 4.70 & 0.60 & 8.07 & 1.42 \\
\hline $\mathrm{I} 4+\mathrm{G}$ & 6.39 & 0.27 & 6.65 & 4.76 & 0.59 & 7.99 & 1.34 \\
\hline $\mathrm{I} 4+\mathrm{A}$ & 5.95 & 0.32 & 6.65 & 5.15 & 0.44 & 7.15 & 0.5 \\
\hline $\mathrm{I} 4+\mathrm{S}$ & 6.09 & 0.33 & 6.65 & 4.84 & 0.67 & 7.49 & 0.84 \\
\hline $\mathrm{I} 4+\mathrm{SM}$ & 6.14 & 0.32 & 6.65 & 4.77 & 0.60 & 7.88 & 1.23 \\
\hline $\mathrm{MD} 2+\mathrm{C}$ & 6.49 & 0.20 & 7.24 & 4.95 & 0.54 & 9.07 & 1.83 \\
\hline $\mathrm{MD} 2+\mathrm{G}$ & 6.41 & 0.22 & 7.24 & 4.91 & 0.57 & 9.01 & 1.77 \\
\hline $\mathrm{MD} 2+\mathrm{A}$ & 5.97 & 0.29 & 7.24 & 5.17 & 0.50 & 8.70 & 1.46 \\
\hline $\mathrm{MD} 2+\mathrm{S}$ & 5.90 & 0.32 & 7.24 & 4.84 & 0.66 & 8.76 & 1.52 \\
\hline $\mathrm{MD} 2+\mathrm{SM}$ & 6.12 & 0.28 & 7.24 & 4.91 & 0.63 & 8.89 & 1.65 \\
\hline $\mathrm{MD} 8+\mathrm{C}$ & 6.40 & 0.21 & 7.28 & 4.81 & 0.59 & 9.38 & 2.1 \\
\hline MD8+G & 6.32 & 0.22 & 7.28 & 4.82 & 0.59 & 9.40 & 2.12 \\
\hline $\mathrm{MD} 8+\mathrm{A}$ & 5.95 & 0.30 & 7.28 & 5.35 & 0.44 & 8.75 & 1.47 \\
\hline MD8+S & 5.91 & 0.31 & 7.28 & 4.84 & 0.67 & 8.43 & 1.15 \\
\hline MD8+SM & 6.04 & 0.29 & 7.28 & 4.84 & 0.60 & 9.40 & 2.12 \\
\hline
\end{tabular}

C: Control, A: Ashwagantha powder, G: Ginger powder, S: Satavari powder, SM: Safed Musli,

V3: Lactobacillus helveticus MTCC 5463, I4: Lactobacillus rhamnosus MTCC 5462,

MD2: Streptococcus thermophilus MTCC 5460, MD8: Streptococcus thermophilus MTCC 5461

\section{Effect on $\mathrm{pH}$}

The $\mathrm{pH}$ of milk just after inoculation (Table 2) varied on the basis of the type of the added herb which showed that herbs themselves contribute to the lowering of $\mathrm{pH}$. As compared to control, all the samples showed $\mathrm{pH}$ reduction after the incorporation of herb powder in the milk. The reduction in milk $\mathrm{pH}$ was due to the inherent phytochemical properties of herbs. The highest $\mathrm{pH}$ reduction was observed in the milk samples added with ashwagandha while least $\mathrm{pH}$ reduction was observed in ginger powder added samples. However, after 8 hours of fermentation, a significant drop in $\mathrm{pH}$ was observed in all cases (Table 2, Figure 1). Among all the cultures, $\mathrm{pH}$ lowered by Ashwagantha was minimum, showing some inhibitory activity to all the cultures during fermentation. Satavari and Safed Musli had similar effects, but of lower order for all the cultures. All the cultures showed no effect of ginger powder incorporation on the $\mathrm{pH}$ of fermented milk. However as compared to control, lowering of $\mathrm{pH}$ was less in Lactobacillus helveticus MTCC 5463, followed by Lactobacillus rhamnosus MTCC 5462, Streptococcus thermophilus MTCC 5460, 
and Streptococcusthermophilus MTCC 5461. Bakirci (8) reported that herbs, in general, contain some amount of carbohydrates, protein, minerals and some vitamins and hence, may serve as an additional source of carbon and nitrogen and can contribute to $\mathrm{pH}$ and titratable acidity.

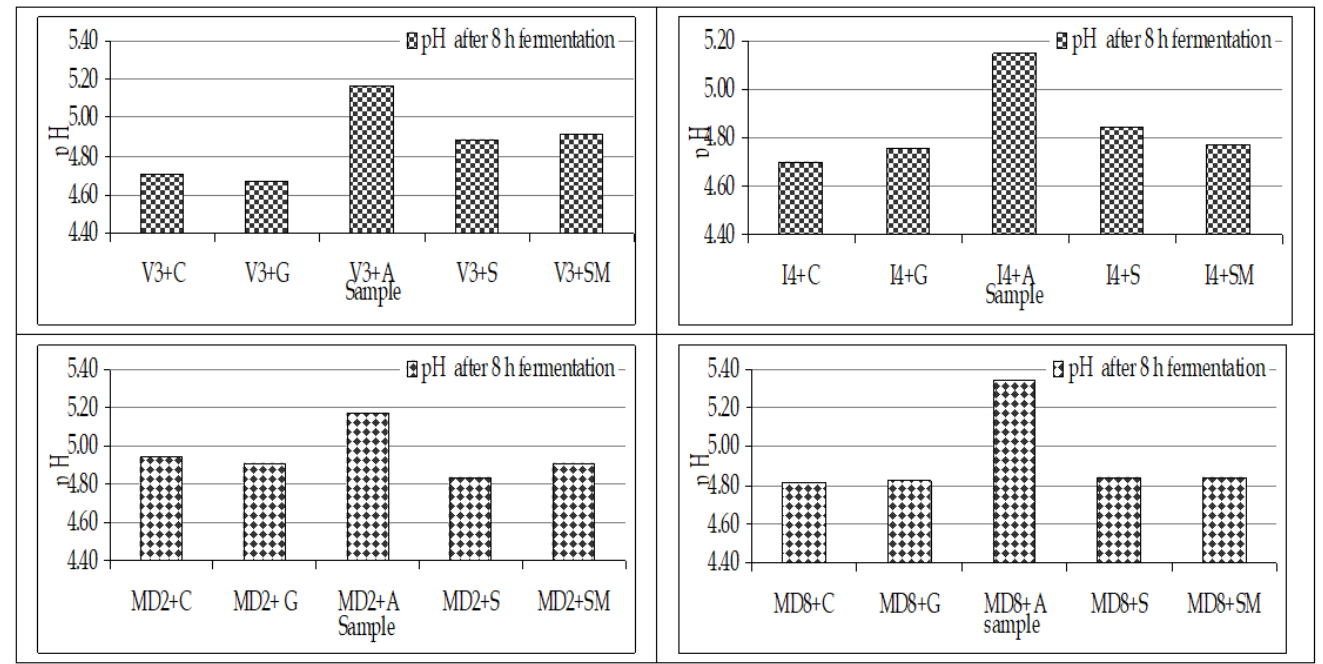

Figure 1. Effects of medicinal herbs on pH of lactic acid bacteria after $8 \mathrm{~h}$ of fermentation in skim milk

\section{Effect on titratable acidity}

The effect of fermentation in the presence of various herbs on the \% lactic acid level is shown in Figure 2 and Table 2. The trend was similar to what was shown in $\mathrm{pH}$. Compared to control samples, ashwagandha suppressed the development of acidity in all cultures. However, Satavari showed higher acid production in all the cultures. The \% lactic acid in Safed Musli added product was comparable to control. Among the cultures, Streptococcus thermophilus MTCC 5460 cultures showed lactic acidity stimulation by Satavari, Safed Musli, and ginger during fermentation; while no or higher lactic acid development was observed in Streptococcus thermophilus MTCC 5461 culture fermented milk along with ginger, Satavari and Safed Musli powder. Bakirchi [8] observed a rise in the titratable acidity with the addition of herbs Alliums sp., and Thmus sp., in medium added with lactic acid bacteria. This indicates that the herb itself can also contribute to acid production.

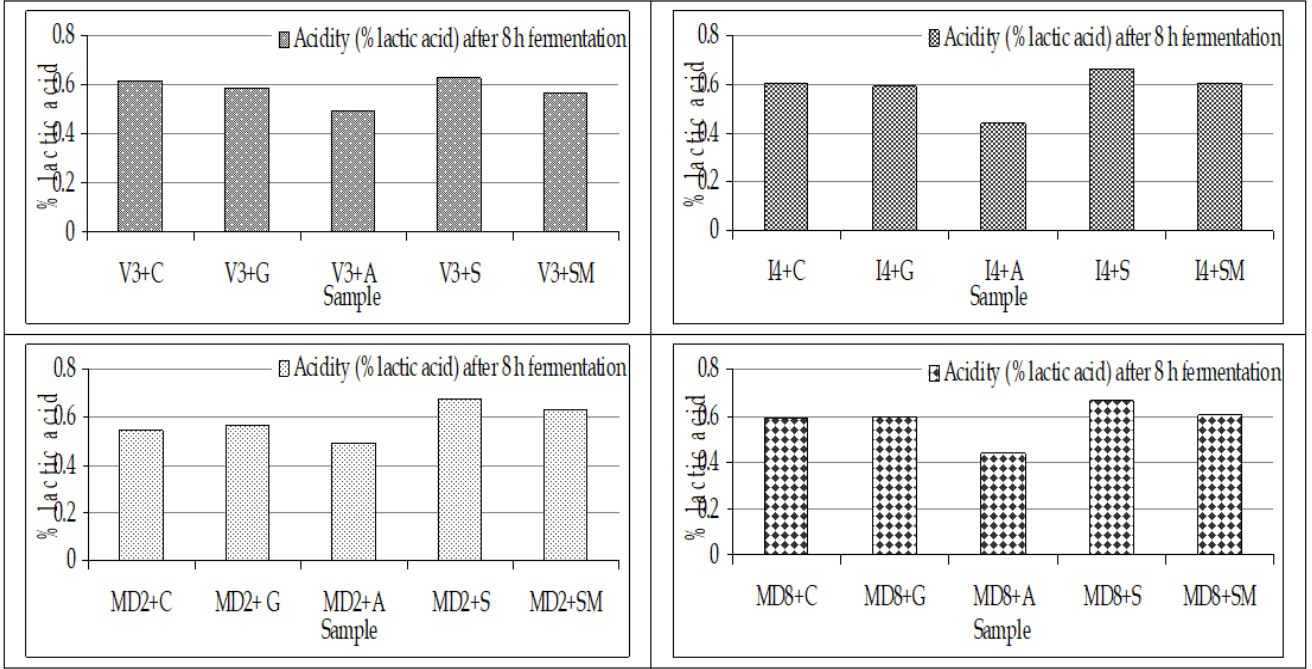

Figure 2. Effects of medicinal herbs on the acidity (\% lactic acid) of lactic acid bacteria after $8 \mathrm{~h}$ of fermentation in skim milk 


\section{Effect on the viable count of lactic acid bacteria}

Estimation of the viable count of lactic acid bacteria after 8 hours of milk fermentation in the presence of medicinal herbs revealed the direct influence of herbs on lactic cultures. The data shown in Table 2 revealed the increase in the viable count from the beginning of fermentation until 8 hours of incubation. The log viable count of Lactobacillus helveticus MTCC 5463 range from 7.66 to 8.42. Control has the highest count followed by ginger, Safed Musli, Satavari and Ashwagandha added samples (Figure 3). The ashwagandha powder showed more growth inhibition against Lactobacillus helveticus MTCC 5463, Lactobacillus rhamnosus MTCC 5462 and Streptococcus thermophilus MTCC 5460. In case of Streptococcus thermophilus MTCC 5461, Satavari suppressed count to highest extent while ginger and Safed Musli powder addition increased the count indicating a stimulatory effect on Streptococcus thermophilus MTCC 5461. The overall viable count was highest in Streptococcus thermophilus MTCC 5461 followed by Streptococcus thermophilus MTCC 5460, Lactobacillus helveticus MTCC 5463, and Lactobacillus rhamnosus MTCC 5462.

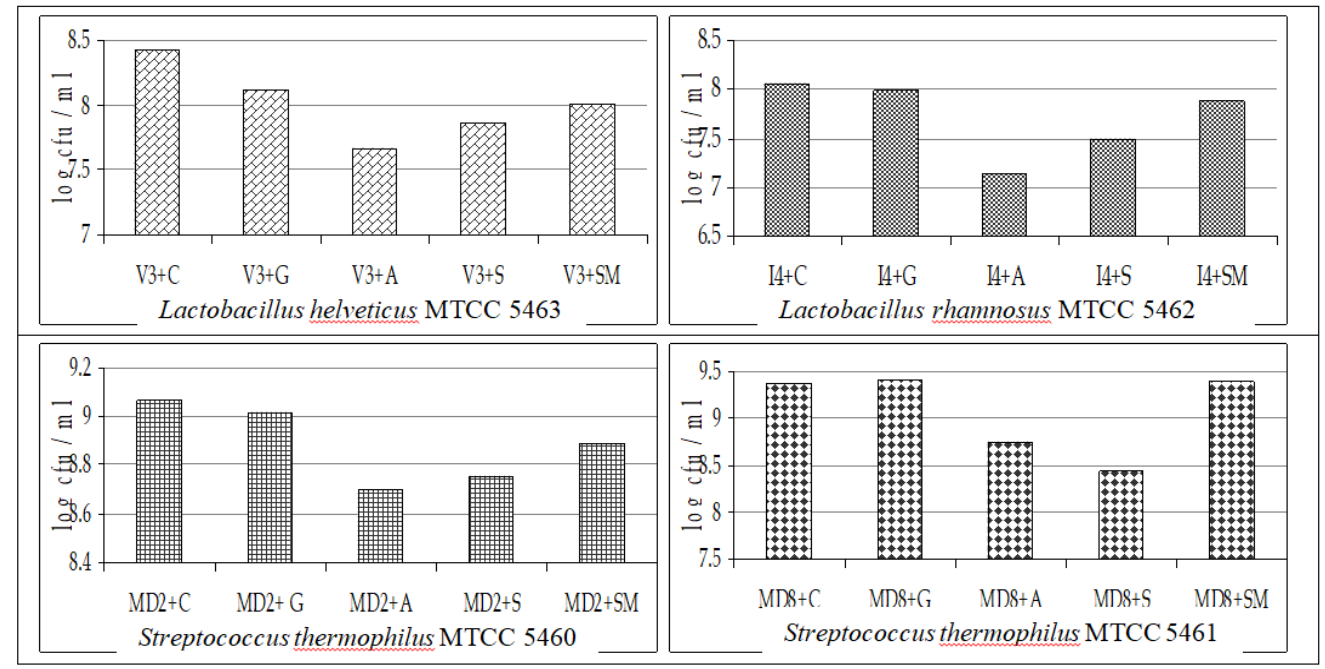

Figure 3. Effects of medicinal herbs on viable log count of lactic acid bacteria after $8 \mathrm{~h}$ of fermentation in skim milk.

The comparative effect of each herb on various cultures is shown in Figure 4. Ginger had the least effect on Streptococcus thermophilus MTCC 5461, but the maximum effect on Lactobacillus rhamnosus MTCC 5462. In the case of Ashwagandha, all cultures were affected adversely; among which Streptococcus thermophilus MTCC 5460 and Streptococcus thermophilus MTCC 5461 was the least inhibited, while the count of Lactobacillus rhamnosus MTCC 5462 and Lactobacillus helveticus MTCC 5463 were most adversely affected as compared to control. Satavari also had the similar trends of inhibition on the growth of all lactic cultures, but comparatively lesser than Ashwagandha. Safed Musli had the lowest inhibitory effect in Streptococcus thermophilus MTCC 5461, but the maximum effect in Lactobacillus helveticus MTCC 5463.

Guo et al. [21] studied the prebiotic effects of the Lentinula edodes extract (LenE), on the growth and cecal microbial ecosystem of chickens and found that a level of $2 \mathrm{~g} / \mathrm{kg} \mathrm{L}$. edodes extract (LenE) promoted the highest bifidobacteria and lactobacilli counts. As per the available literature, limited studies are present to show the effect of incorporation of Ginger, Satavari, Safed Musli or Ashwagandha on lactic acid bacteria during milk fermentation. 


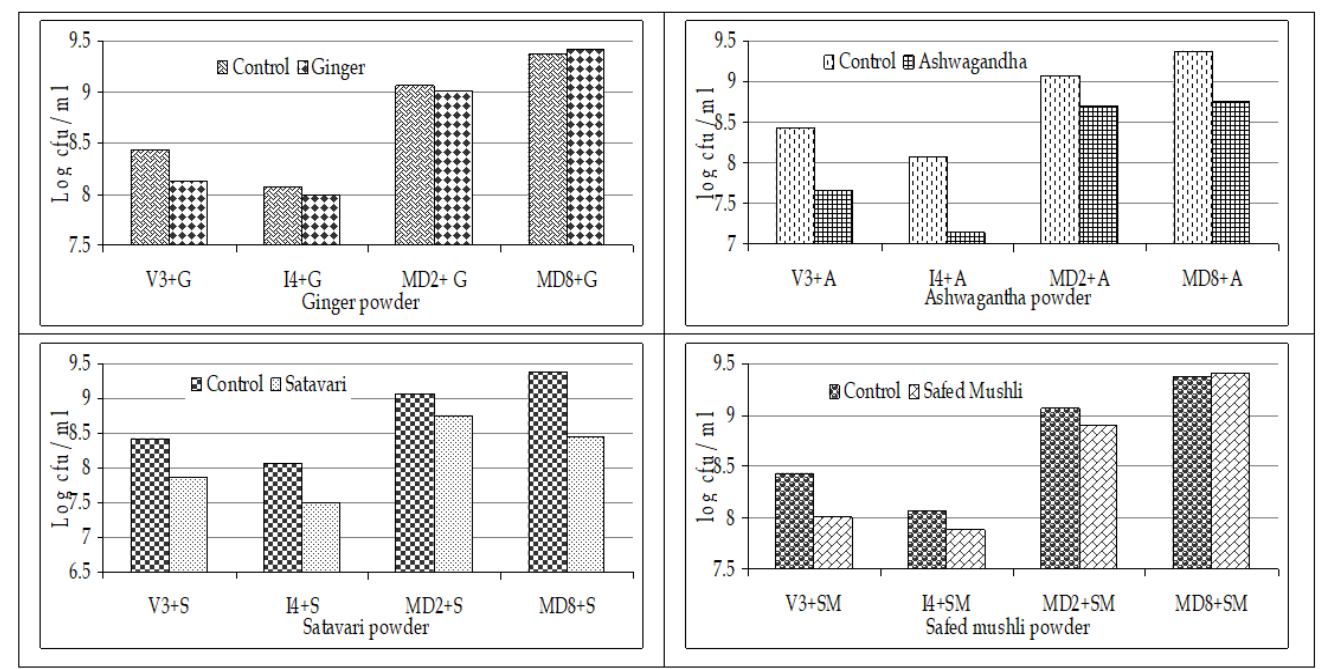

Figure 4. Performance of different cultures in skim milk added with herbs

\section{Conclusion}

This study examined the antimicrobial activity of four medicinal herbs viz., ginger, Ashwagandha, Satavari and Safed Musli by cup well assay technique as well as by measurement of $\mathrm{pH}$, titratable acidity and log viable count of lactic acid bacteria viz., Lactobacillus helveticus MTCC 5463, Lactobacillus rhamnosus MTCC 5462, Streptococcus thermophilus MTCC 5460 and Streptococcus thermophilus MTCC 5461 in skim milk after culture (@2\%v/v) inoculation $(0 \mathrm{~h})$ and after $8 \mathrm{~h}$ of fermentation in presence of herbs (@1\% w/v). Out of four herbs, the Ashwagandha powder had the highest inhibitory effect followed by Satavari powder. Ginger and Safed Musli powder did not have any inhibitory activity on the four test cultures. Screening of herbs by growth pattern of lactic acid bacteria in fermented milk revealed that Ashwagandha had maximum inhibitory effect on selected lactic dairy cultures followed by Satavari while ginger and safed musli addition @ $1 \%$ in skim milk had no negative effects on growth of lactic acid bacteria as tested by viable cell count, percent lactic acid development and $\mathrm{pH}$ measurement.

\section{References}

[1] N. Shah, J. B. Prajapati and A. Jana (2009). Fizzy fermented milk products-a viable alternative to soft drinks. Ind Food Indus (AFSTI), 28: 39-44.

[2] P. Thakkar, H. A. Modi and J. B. Prajapati (2015). Isolation, characterization and safety assessment of lactic acid bacterial isolates from fermented food products. Int. J. Curr. Microbiol. Appl. Sci., 4: 713725.

[3] Z. F. Bhat and H. Bhat (2011). Milk and Dairy Products as Functional Foods: A review. Int. J. Dairy Sci., 6: $1-12$.

[4] S. M. El-Sayed and A. M. Youssef (2019). Potential application of herbs and spices and their effects in functional dairy products. Heliyon, 5: e01989.

[5] C. L. Chan, R.Y. Gan, N. P. Shah and H. Corke (2018). Polyphenols from selected dietary spices and medicinal herbs differentially affect common food-borne pathogenic bacteria and lactic acid bacteria. Food Control, 92: 437-443.

[6] T. Bintsis (2018). Lactic acid bacteria: their applications in foods. J Bacteriol Mycol., 6: 89-94.

[7] N. Shah and J. B. Prajapati (2014). Effect of carbon dioxide on sensory attributes, physico-chemical parameters and viability of Probiotic L. helveticus MTCC 5463 in fermented milk. J Food Sci Technol., 51: 3886-3893.

[8] I. Bakirci (1999). The effects of some herbs on the activities of thermophilic dairy cultures. Nahrung, 43: 333-335. 
[9] H. Coşkun (1998). Microbiological and biochemical changes in herby cheese during ripening. Nahrung., 42: S309- 313.

[10] L. L. Zaika and J. C. Kissinger (1979). Effects of some spices on acid production by starter cultures. J. Food Protection., 42: 572-576.

[11] J. B. Prajapati, C. D. Khedkar, J. Chitra, S. Suja, V. Mishra, V. Sreeja and R. K. Patel et al. (2011). Whole-genome shotgun sequencing of an Indian-origin L. helveticus strain, MTCC 5463, with probiotic potential. J. Bacteriol., 193: 4282-4283.

[12] M. N. Ashar and J. B. Prajapati (2001). Serum cholesterol levels in humans fed with Acidophilus milk. Ind J Microbiol., 41: 257-263.

[13] S. K. Patidar and J. B. Prajapati (1999). Effect of feeding lactobacilli on serum antibody titer and faecal microflora in chicks. Microbiol, Aliments, Nutri., 17: 145-154.

[14] V. Kodaikkal, J.B. Prajapati and A. Ljungh (2012). Evaluation of adhesion of Lactobacillus strains to HT-29 cells by a flow cytometric assay. Int. J. Appl. Animal Sci., 1: 1-7.

[15] J. B. Prajapati, R. I. Dave and S. S. Sannabhadti (1995). Evaluation of perfor- mance of S. thermophilus and L. acidophilus in buffalo milk. I. J. Dairy Sci., 48: 525-528.

[16] S. K. Patidar and J. B. Prajapati (1998). Standardization and evaluation of lassi prepared using Lactobacillus acidophilus and Streptococcus ther- mophilus. J. Food Sci. Technol., 35: 428-431.

[17] Indian Standards (1960). IS: 1479. Methods of testing for dairy industry. Part-I. Rapid examination of milk. Indian Standards Institution, New Delhi.

[18] IDF Standards 117 A (1989). Yoghurt enumeration of characteristic microorganism colony count technique at $37^{\circ} \mathrm{C}$.

[19] Indian Standards (1962) IS: 1479. Method of test for Dairy industry. Part III. Bacteriological Examination of Milk. Indian Standards Institution, New Delhi.

[20] H. S. Lee and Y. J. Ahn (1998). Growth-Inhibiting Effects of Cinnamomum cassia Bark-Derived Materials on Human Intestinal Bacteria. J. Agric. Food Chem., 46: 8-12.

[21] F. C. Guo, B. A. Williams, R. P. Kwakkel, H.S. Li, X.P. Li, J. Y. Luo and W. K. Li (2004). Effects of mushroom and herbs polysaccharides, as alternatives for an antibiotic, on the cecal microbial ecosystem in broiler chickens. Poult. Sci., 83: 175-182. 